KATEŘINA VOLEKOVÁ

Ústav pro jazyk český AV ČR

\title{
Znaménko rozlišovací a zdůrazňovací ve staročeských rukopisech ${ }^{1}$
}

Někdy na konci 50. let 15 . století si opsal tehdejší učitel a pozdější kněz Oldřich Kř́ž z Telče do svého rukopisného sborníku latinský traktát o českém pravopisu². Spis nazývaný uzuálně Orthographia Bohemica se především podrobně věnuje výkladu, jak by se měla v českém zápise užívat diakritická znaménka namísto spřežek (qui vis Bohemice scribere, habes differencias literarum positas et noli ponere duplex zz cum vocalibus, quia si centum $\mathrm{z}$ pones, non facient plus in sono vel aliter quam z, sed pone ż Orth $41 \mathrm{v})^{3}$. Pro názornost je rozbor doplněn četnými př́klady jednotlivých př́padů (např. Ż [Ž] ponitur circa a ut in żak [žák], circa e ut žena, circa i ut žid, circa o raro et hoc in medio ut in krzyzowany [křižovaný] Orth 40v). Kř́iž si celý text opsal do rukopisu pro svou vlastní potřebu a pedagogickou praxi, ale již při samém opisu nebyl s to důsledně aplikovat poučku o tom, kde psát literu s diakritickým znaménkem a kde bez něj.

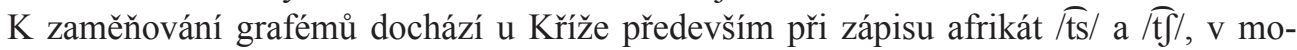
derním českém pravopise zapisovaných grafémy $<\mathrm{c}>\mathrm{a}<\breve{c}>$. V odstavci, kde se pojednává o psaní těchto konsonantů, označuje Kříž v zápise grafy diakritikou velmi zmatečně: $\mathrm{v}$ prvním příkladě neznačí v rozporu s požadavky vymezenými $\mathrm{v}$ traktátu hlásku $/ \mathrm{t} \mathrm{g} / \mathrm{ve}$ všech případech grafem s diakritickým znaménkem, ale použivá kromě grafu $<\mathrm{c}>\mathrm{i}$ trigraf $<\mathrm{czz}>$ (př́klad č. 1). $\mathrm{V}$ druhém př́ipadě $\mathrm{v}$ rozboru afrikáty /ts/ některá př́kladová slova $\mathrm{s}$ touto hláskou na začátku slova zapíše mylně grafem $\mathrm{s}$ háčkem (př́íklad č. 2). A poté do-

${ }^{1}$ Př́íspěvek byl podpořen projektem GA ČR č. 16-00598S Orthographia Bohemica a náměštská mluvnice (filologická analýza a kritické edice).

${ }^{2}$ Třeboň, Státní oblastní archiv v Třeboni, sign. A 4, ff. 35r-42r, konec 50. let 15. století, dále Orth. Digitální kopie rukopisu a základní charakteristika traktátu spolu se seznamem literatury jsou dostupné online na WWW: <http://vokabular.ujc.cas.cz/moduly/mluvnice/digitalni-kopie-info/Orth>.

${ }^{3}$ Latinský text transkribujeme podle obecných zásad pro přepis bohemikálních latinských textů (srov. nepublikované zásady Bohumila Ryby; Vidmanová 1985); český text transliterujeme a v hranatých závorkách [] uvádíme trankripci, pokud se od transliterované podoby liší, podle obecných zásad pro přepis starších českých textů (srov. Daňhelka 1985). Písařské zkratky rozepisujeme v kulatých závorkách () a znaménka nad písmeny standardizujeme a přepisujeme bud' jako tečku, háček, nebo čárku. Grafy a grafémy umistujeme do špičatý závorek $\diamond$ a fonémy, které přepisujeme podle mezinárodní fonetické abecedy (IPA), klademe mezi dvě lomítka //. 
konce u všech vzorových slov s hláskou /ts/ ve finální pozici zaznamená poslední písmeno překvapivě s háčkem (př́klad č. 3). Také v zápise českých textů na konci spisu, které mají ilustrovat aplikaci v traktátu popsaného pravopisného systému využívajícího diakritických znamének pro vzájemné rozlišování grafémů, píše Kř́íz hlásky $\widetilde{\mathrm{ts}} /$ a $\overparen{\mathrm{t}}$ / chaoticky třemi různými grafémy $<\mathrm{c}>,<\mathrm{cz}>,<\breve{c}>$ (př́klad č. 4).

(1) Tercio notandum, quo c [č] ponitur circa a in principio ut čakay [čakaj], circa e ut čechu [Čechu], circa i ut činy, ut dicatur: čakay, czzechu, czziny [čakaj, Čechu, činy] Orth $36 \mathrm{v}$

(2) Sed c precedit omnes vocales in principio, a in hac diccione cac, e ut cecik [cecík], $\mathrm{i}$ in cizi [cizí], u in čudny [cudný], o in čo fi [co si], idest quid es Orth 36v

(3) Similiter c sequitur in fine omnes vocales, ut plač [plac], leč [lec], noč [noc], plič [plic], tluč [tluc] Orth 37r

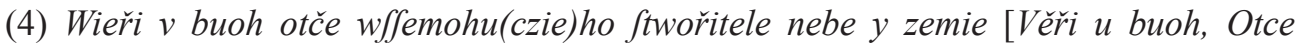
všemohúcieho, stvořitele nebe $i$ zemé];

Sedi na p(ra)wiči boha otče w⿰`emo(huczi)ho [sedi na pravici boha Otce všemohúcieho];

Wieři w ducha fwaté(h)o fwatu čierkew obecznu fwatych občowanié [Věři v ducha svatého, svatú cierkev obecnú, svatých obcovánie] Orth 41v

Je škoda, že neexistuje jiný kompletní opis traktátu Orthographia Bohemica, než je onen Kř́žůuv, jehož vznik je datován do 50. let 15. století. Stručný výtah z latinského traktátu, který pochází přibližně ze stejné doby, nebo je o trochu staršíi ${ }^{4}$, byl opsán z jiné předlohy a jeho písař diakritická znaménka v zápise konsonantů /ts/ a / T $/$ užíval bez problému (např̀.: $\dot{C}$ [Č ]: ċkai, ċechu, čýni [čkaj, Čechu, činy] OrthVýtah 243v) ${ }^{5}$. Jedná se tedy pouze o to, že Kříž neporozuměl navrženým zásadám? Nebo je to dozvuk jiného, zažitého písařského úzu?

V tomto př́spěvku se pokusíme zjistit, zda by se odpověd' na tyto otázky nedala najít $\mathrm{v}$ jiných staročeských rukopisech, a to hlavně v rukopisech biblických, které jsou ze staročeského období dochovány v neobvyklé kvantitě a různorodé kvalitě zápisu.

Diakritický pravopis ${ }^{6}$ tak, jak je formulován v traktátu Orthographia Bohemica, je písaři v první polovině 15 . století reflektován poměrně málo, důsledněji je používán jen v několika rukopisech. K nejznámějším patří opis Husových děl ve sborníku Zikmunda z Domažlic z roku 1414 (tzv. Hořčičkưv v ). O rok starší je pravděpodobně tzv. annaberský dopis, diktovaný mistrem Janem Husem písaři Plebanovi někdy mezi druhou polovinou prosince

${ }^{4}$ Praha, Archiv Pražského hradu, Knihovna Metropolitní kapituly u sv. Víta, sign. D 19, ff. 253v-254r, dále OrthVýtah; srov. Vidmanová 1982.

${ }_{5}^{5}$ Odstavec pojednávající o hlásce /ts/ stejně jako české př́ikladové texty (Otče náš, Zdrávas a Věřím) jsou ve výtahu bohužel vynechány.

${ }^{6}$ Obecně k vývoji českého pravopisu srov. Pleskalová 2016a; 2016b; Pleskalová, Kosek 2016;.

${ }^{7}$ Praha, Knihovna Národního muzea, sign. IV C 18, obsahuje HusPostH, HusBludM, HusDcerkaH. Pro staročeské prameny užíváme zkratky podle Staročeského slovniku (SS 1968), pro zde nezachycené prameny vytváříme analogické zkratky. 
1412 a koncem února 1413, v něm však nejsou diakritická znaménka užívána zcela důsledně (Michálek, Němec, Spunar 1984).

Diakritickým pravopisem, který rozlišuje v zápise tvrdé $t$ a střední $l$ podle pokynů traktátu Orthographia Bohemica, jsou psány pouze dva biblické rukopisy z raného husitského období: česká Bible boskovická, zapsaná zřejmě mezi léty $1421-1425^{8}$ a české meziřádkové glosy v latinském žaltáři s výkladem z doby kolem roku $1420^{9}$. Většina rukopisných záznamů 15. století je však psána kombinací spřežkového a diakritického pravopisu, přičemž poměr spřežek vůči grafémům s diakritikou různě kolísá v závislosti na písaři, době sepsání, mírue reprezentativnosti rukopisu apod. Nezrrídka se objevují také rukopisy, které vedle grafémů s diakritickým znaménkem, užívají i méně obvyklé grafémy se znaménkem zdůrazňovacím, tj. znaménkem, které daný znak pouze zdůrazňuje, ale nedává mu odlišný význam.

Znaménko ve tvaru tečky, čárky, obloučku, háčku či vlnovky plní ve středověkém grafickém záznamu textu - bez ohledu na použitý jazyk - rozličnou funkci, může nést informaci o zkrácení slova a v zápise zastupovat i několik znaků (např. $<\mathrm{p}>=$ per, $<\mathrm{p}>=$ pro), nebo se může jednat o znaménko vztahující se k jednomu konkrétnímu znaku, které bud' znak pouze zdůrazňuje, či naopak dává znaku odlišný význam. V českém písmu užívaném ve středověku je tedy graf se znaménkem bud' jen variantou grafému, tedy alografem, a má stejný význam (např. alografy $<1>,<\mathrm{i}>,<\hat{i}>$, nebo $<\mathrm{y}>,<\dot{y}>,<\ddot{y}>,<\ddot{y}>$ v platnosti fonému $/ \mathrm{I} /$ ), nebo jiný grafém s odlišným významem, než má graf bez znaménka (např. $<\mathrm{z}>=/ \mathrm{z} /$, $<\check{z}>=/ 3 / \mathrm{v}$ diakritickém pravopise). V prvním případě se jedná o znaménko zdůrazňovací, v druhém př́ipadě jde o znaménko rozlišovací, diakritické.

Variantní zápis grafému, a to složený graf se zdưrazňovacím znaménkem, slouží především k výraznějšímu a jednoznačnějšímu odlišení realizací tohoto grafému od realizací podobných grafémů. Nejznámějším př́ípadem je graf $<\mathrm{i}>\mathrm{s}$ tečkou nebo vlasovou čárkou (Daňhelka 1985: 293-294). Znaménko má zvláště v gotickém písmu, ale později i v bastardě a humanistickém písmu čtenáři usnadnit čtení a pomoci odlišit tento grafém, skládající se $\mathrm{z}$ jednoho dř́ḱku, od dříků jiných grafémů, zvl. ve spojení s písmeny $m, n, u$ apod (Muzika 1958: 260, 301, 307). Stejnou funkci mívá znaménko nad grafem $<y>$, nezř́idka také v podobě dvou teček či čárek. Tato znaménka mají odlišit graf $<\mathrm{y}>$ od grafů $<\mathrm{v}>$ či $<\mathrm{u}>$, protože při zběžném psaní často dochází $\mathrm{k}$ tomu, že spodní dřík písmene $<\mathrm{y}>$ není dostatečně zřetelný a grafy $<\mathrm{v}>,<\mathrm{u}>\mathrm{a}<\mathrm{y}>$ splývají. Ke splynutí v písmu může docházet také u grafi̊ $<\mathrm{c}>\mathrm{a}<\mathrm{t}>$, které je $\mathrm{v}$ některých zběžnějších zápisech těžké od sebe odlišit.

Naopak graf se znaménkem s rozlišovací funkcí označuje jiný foném než graf bez diakritiky. Takovou funkci mají diakritická znaménka v některých cizích jazycích (např. hebrejština, řečtina, němčina) a středověcí vzdělanci se s tímto odlišným systémem setkávali jak v praxi, tak v teoretických pracích ${ }^{10}$. Tento odlišný princip začal být postupně uplatňován i v českém pravopisném systému.

8 Olomouc, Vědecká knihovna v Olomouci, sign. M III 3, BiblBosk; srov. Hrbáčová, Krušinský $2016: 272$. Udává se též datace o málo starší, mezi léty 1414-1419, srov. Gaudek 2012.

9 Praha, Národní knihovna ČR, sign. X B 22, ŽaltGlosKlem. České glosy (jen do Ps 118,3; ff. 1r-207r) se hlásí k prvnímu překladu žaltáře, srov. Kyas 1962: 12.

${ }^{10} \mathrm{~K}$ možným inspiracím diakritického pravopisu srov. Šlosar 2010. 
Ve starších písemných záznamech českých textů se grafémy se znaménky objevují ojediněle již od 12. století. Nejstarší doklad na označení kvantity pomocí čárky je nejspíš osobní jméno Nóstup (< Neostup) v administrativní listině z roku 1188 (Noóstup Codex diplomaticus et epistolaris regni Bohemiae $\mathrm{I}^{11}$, s. 294; srov. Pleskalová 1998: 137), jedná se však o výjimečný doklad. Obecně se v českých rukopisech dř́ve a ve větší míře rozšířila znaménka se zdůrazňovací funkcí.

Zdůrazňovací znaménka nacházíme v první polovině 14. století ve zlomcích nejstarších legend, např. u grafu $<\dot{y}>$ funguje tečka jako zdůrazňovací znaménko, které ho odlišuje od grafu $<\mathrm{v}>$ např. chodẏla [chodila] (LegJidD). Rukopis toho času nezvěstný, dříve Schlägl; srov. Cejnar 1964: 156. Nejinak tomu je později u biblických rukopisů: klementinský zlomek biblické knihy Genesis ve znění první redakce z poloviny 14. století užívá grafém <í'> $\mathrm{s}$ vlasovou čárkou ${ }^{12}$ a v rukopisu Evangelia sv. Matouše s homiliemi ze 70. let 14. století je nepravidelně zapisován $\mathrm{s}$ vlasovou čárkou jak grafém $\left\langle\hat{i}>\right.$, tak grafém $\langle\dot{y}\rangle^{13}$. Též opis knihy Zjeveni svatého Jana první redakce z 80 . let 14. století, který byl později přivázán $\mathrm{k}$ Novému zákonu klementinskému glosovanému z roku $1426^{14}$, je psán spřežkovým pravopisem, který využívá znaménka pro zdůraznění grafému $<\mathrm{y}>$ (např. wydyety் [viděti] BiblKlemNZ 233r, hodÿnÿ [hodiny] BiblKlemNZ 344r).

Systém pro označování odlišných českých fonémů prostřednictvím grafémů s diakritickým znaménkem se $\mathrm{v}$ českém písemném záznamu začíná utvářet $\mathrm{v}$ druhé polovině 14. století, ale písemně je zformulován a důsledně propracován až právě v anonymním latinském traktátě Orthographia Bohemica. Zde neznámý autor, podle mnoha badatelů možná kazatel a reformátor M. Jan Hus, pečlivě popsal pravopisný systém odlišný od běžného, který je velmi vhodný pro češtinu a $\mathrm{v}$ kterém grafém složený $\mathrm{z}$ grafu a diakritiky ve formě tečky označuje konsonant, který nemá latinský jazyk (si non ponitur punctus rotundus super litera aliqua ex iam dictis, tunc debet pronuncciari more Latinorum. Sed si ponitur punctus desuper, tunc ad ydioma Boemicum debet flecti Orth 36r), tj. $\langle\dot{\mathrm{c}}>=/ \widetilde{\mathrm{f}} /,<\mathrm{d}>=| \mathrm{y} /,<\dot{\mathrm{n}}>=$

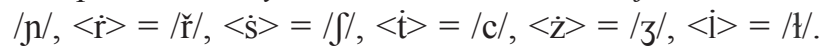

Náběhy $\mathrm{k}$ diakritice se objevují již $\mathrm{v}$ předhusovských rukopisech, značky pro délku a měkkost však byly užívány sporadicky (Gebauer 1878: 219-220). Kvantita bývá označována čárkou např́klad v klementinském sborníku Tomáše Štítného ze Štítného z roku $1376^{15}$. Z biblických rukopisů to jsou tzv. Proroci rožmberští z 90. let 14. stoletî́16, jejichž písař ojediněle užívá tečky nad palatálami (pofkwrinyly [poskvrnili] Pror 1ra, hrżyeffnyky [hřiešniky] Pror 2ra). Z druhé poloviny 14. století a následně z přelomu století pocházejí i některé rukopisné zlomky biblí, v nichž se nacházejí náznaky diakritického pravopisu (př́íklady č. 5-8):

${ }^{11}$ Codex diplomaticus et epistolaris regni Bohemiae je dostupný online: $<$ http://147.231.53.91/src/index. $\mathrm{php} ? \mathrm{~s}=\mathrm{v} \&$ cat $=2 \&$ bookid $=76>$.

12 Praha, Národní knihovna ČR, sign. XVII J 17/10.

13 Praha, Národní knihovna ČR, sign. XVII A 4, MatHom.

${ }^{14}$ Praha, Národní knihovna ČR, sign. XVII E 13, BiblKlemNZ.

15 Praha, Národní knihovna ČR, sign. XVII A 6, ŠtítKlem; srov. Gebauer 1894: 90.

16 Praha, Národní knihovna ČR, sign. XVII D 33, Pror; srov. Stejskal 1986; Kyas 1971: 18. 
(5) zlomek Markova evangelia z let 1370-1390, např.: widyel [viděl], lidi [lidi], wzlożi [vzloži], pufti $\left[\right.$ pusti] ${ }^{17}$;

(6) zlomek Skutků apoštolských z 2. poloviny 14. století, např.: geżíffów [Ježišóv], yakż [jakž], ufud'yli [usúdili], vcziniti [učiniti] ${ }^{18}$;

(7) zlomek Druhé knihy Makabejské z přelomu 14. a 15. století, např.: kdyż [když], gużto [južto], zbity [zbiti] ${ }^{19}$;

(8) zlomek Skutků apoštolských z přelomu 14. a 15. století, např.: żzidow [z Židóv], mvżow [mužóv], wiezè் [vе̌zeň ${ }^{20}$.

K. Kučera (Kučera 1998: 182) v sondě věnující se účinnosti a složitosti českého pravopisu ukázal, že ve staročeském období je diakritický pravopis důsledněji využíván až v textech z poloviny 15 . století, ale v druhé polovině 15 . století se opět vyskytuje více spřežek na úkor diakritiky. Při popisu písma užitého v českých celých biblích konstatoval J. Eliáš (Eliáš 1971: 12-18), že v biblích psaných kaligrafickou bastardou sklonku václavského období (1410-1420) převažuje spřežkový pravopis nad diakritickým; v biblích zapsaných běžnou bastardou husitského období (1420-1440) je na rozdíl od předcházejícího období užíváno více nebo méně důsledného diakritického pravopisu, vyznačovaného tečkami; a pro písaře píśící kaligrafickou bastardou období poděbradsko-vladislavského (1440-1460) a pozdější doby (1460-1480) je diakritický pravopis pravidlem.

V biblických pramenech se setkáváme také s užitím diakritických znamének v takové funkci, která nebyla v traktátu Orthographia Bohemica navržena a jedná se o individuální vylepšení diakritického pravopisu pozdějšími písaři. Patří mezi ně např́klad složený graf $<\dot{\mathrm{g}}>$ pro záznam fonému /g/ převážně $\mathrm{v}$ cizích a přejatých slovech. V tomoto př́padě diakritické znaménko odlišuje znak od grafému $<\mathrm{g}>$ pro foném $/ \mathrm{j} /$. Grafém $<\dot{\mathrm{g}}>$ byl nepravidelně užíván druhým písařem Nového zákona Dobrovského ${ }^{21}$ (např. angel gabriel [anjel Gabriel] BiblDobrNZ 212r) a později pravidelně písařem Nového zákona brémského ${ }^{22}$ (např. do kragin galileyfkych [do krajin galilejských] BiblBrémNZ 4vb).

Grafémy se zdůrazňovacím znaménkem užívají čeští písaři po celý středověk, a to i v době, kdy postupně pronikaly prvky diakritického pravopisného systému do užívání. Není proto výjimkou ani text, ve kterém se vedle grafémů s diakritickým znaménkem objevují běžně grafémy se zdůrazňovacím znaménkem, nap̌r. zdůrazňovací znak ve formě tečky či vlasové čárky u grafému $<i>$ byl nadále užíván i v záznamu psaném diakritickým

17 Praha, Národní knihovna ČR, sign. XVII J 17/23-1. Písař ,měkké hlásky označuje tečkou nad literou, délky čárkou tenkou; není to sice provedeno důsledně, ale nikdy odchylně““ (Flajšhans 1891: 92).

18 Praha, Knihovna Národního muzea, sign. 1 A c 80.

19 Praha, Knihovna Národního muzea, sign. 1 A c 2/11.

20 Praha, Knihovna Národního muzea, sign. 1 A c 10.

${ }^{21}$ Budapest, Egyetemi Könyvtár, sign. Cod. Slav. 6, 1417, dále BiblDobrNZ.

22 Bremen, Staats- und Universitätsbibliothek Bremen, sign. msc 0020, 1477, dále BiblBrémNZ. 
pravopisem, v kterém většinou znaménka u grafů plní jinou roli, a zůstal součástí grafému $<$ i $>$ až do dnešní doby.

Avšak v době, kdy nebyl diakritický pravopis v češtině rozšířený a jeho princip mezi vzdělanci obecně známý a písaři důsledně užívaný, docházelo k tomu, že znaménko u téhož grafému mohlo mít u jednoho písaře funkci zdůrazňovací, u druhého písaře naopak funkci rozlišovací. Jde především o značení kvantity vokálu /i:/ pomocí diakritické čárky versus starší systém joty a ypsilonu se zdůrazňovací čárkou. S podobnou nejednoznačností ve významu znaménka se setkáme i u konsonantů. Týká se především českého grafému $<\dot{\mathrm{c}}>$, později též $<\check{\mathrm{c}}>$, u kterého může mít znaménko v rukopisných textech 15 . století dvojí funkci. V prvním prípadě odlišuje znaménko grafém $<\dot{\mathrm{c}}>\mathrm{v}$ platnosti fonému $/ \mathrm{t} \int /$ od grafému $<\mathrm{c}>$ označujícího foném $/ \mathrm{ts} / . \mathrm{V}$ druhém případě znaménko slouží pro zdůraznění písmene $\langle\mathrm{c}>$ a jeho odlišení od grafému $\langle\mathrm{t}\rangle$; s tímto druhem znaménka je grafém $<\dot{\mathrm{c}}>$ navíc polysémní, nebot' může označovat jak foném / Ts/, tak foném / $\widehat{t} /$. V českém pravopisném systému, pokud nebereme v úvahu značení kvantity, se jedná o výjimečný př́pad, ale z hlediska dokladů ne ojedinělý, alespoň ne v biblických rukopisech. Uved'me několik príkladů.

Grafém $<\dot{\mathrm{c}}>$ se zdůrazňovacím znaménkem v platnosti fonémů $/ \mathrm{ts} / \mathrm{i} / \widehat{\mathrm{t}} /$ použil v biblických rukopisech zřejmě nejprve písař souboru biblických předmluv v druhém svazku Bible litoměřicko-třeboňské23, a to jen občasně, nepravidelně (např. boha otċe [boha Otce] ProlBiblL 143vb, mudrćow [mudrcóv] ProlBiblL 144ra, naucitele [naučitele] ProlBiblL 144ra). Dalším podobným rukopisem je již zmiňovaný Nový zákon klementinský glosovaný z roku 1426, jehož písař píše převážně spřežkovým pravopisem a jen výjimečně užívá

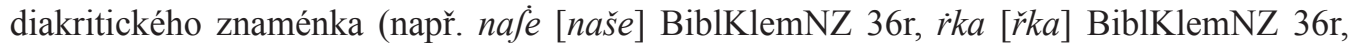
$43 r, 44 v)$. Stejně zrrídka se u něj objevuje grafém $<c>$ se zdůrazňovacím znaménkem $\mathrm{v}$ platnosti fonémů $/ \mathrm{ts} / \mathrm{i} / \widetilde{\mathrm{t}} /$ (např. weecko [všecko] BiblKlemNZ 35r, ćlowleka [člověka] BiblKlemNZ 35v).

Písař, který k Novému zákonu krumlovskému z druhé čtvrtiny 15. století dopsal kombinací spřežkového a diakritického pravopisu na ff. 281 r-338v rejstř́ik perikopních čtení24, užíval zdůrazňovacích znamének nejen pro grafy $<\mathrm{i}>\mathrm{a}<\mathrm{y}>$, ale také pro další písmena:

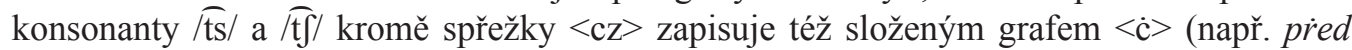
obliciegem [před obličejem] BiblKrumlNZ 282v; cínie ty wjècky wieci [ čině ty v̌̌ecky věci] BiblKrumlNZ 283r; to oni flyffiece zakrućowachu fe w frdcich [to oni slyšiece zakrucováchu se v srdcích] BiblKrumlNZ 284v), čímž ve svém, poněkud zběžném zápise jasně tento grafém odlišuje od zápisu konsonantu $<\mathrm{t}>$. Výjimečně také složený graf $<\dot{\mathrm{c}}>$ najdeme ve spřežce $<\mathrm{ch}>$, která označuje velární frikativu /x/ (pred ocíma wiech [před očima v̌̌ech] BiblKrumlNZ 284v), a velmi často také grafém $<\dot{Z}>$ se zdůrazňovacím znaménkem označuje oba fonémy /z/ a /3/ (flużebnikì [služebniky] BiblKrumlNZ 283r; na żemy [na zemi] BiblKrumlNZ 284r). Je evidentní, že v tomto rukopise užívání znamének ztrácí systémovost a pravopis se stává z čtenářského hlediska málo účinným.

I v některých Nových zákonech z druhé poloviny 15. století se objevuje grafém $<\dot{\mathrm{c}}>$ $\mathrm{v}$ platnosti fonémů $\widetilde{\mathrm{ts}} / \mathrm{i} / \widetilde{\mathrm{t}} /$. Např́klad písař Nového zákona s Umučením z 60. let 15.

${ }^{23}$ Litoměřice, Státní oblastní archiv v Litoměřicích, fond Biskupské sbírky Litoměřice, sign. BIF 3.1, kolem 1413, ff. 144r-173r, ProlBiblL.

24 Praha, Knihovna Národního muzea, sign. III E 28, druhá čtvrtina 15. století, BiblKrumlNZ. 
století $^{25}$ píše kombinací spřežkového a diakritického pravopisu a často vyznačuje tečkou palatální konsonanty (např. $\langle\dot{\mathrm{P}}\rangle,\langle\dot{\mathrm{z}}\rangle,\langle\dot{\mathrm{t}}\rangle,<\dot{\mathrm{r}}\rangle,<\dot{\mathrm{d}}>$ ), avšak grafémem $<\dot{\mathrm{c}}>$ označuje jak foném $/ \mathrm{t} \widehat{\mathrm{S}} /$, tak $/ \overparen{\mathrm{t}} /$ (např. Nebudte pec்lıwi duffi fwe ćo by gedli [Nebud'te pečlivi duši své, co by jedli] BiblUmučNZ 4ra; otcie wjeçky wieci fu możne tobie [otče, všecky věci sú možné tobě] BiblUmučNZ 33va). Podobná je situace v Novém zákoně Václavově ze stejného obdobíi ${ }^{26}$, kde se objevuje jednak diakritické znaménko pro palatály, jednak zdůrazňovací znaménko pro graf $<\mathrm{c}>\mathrm{v}$ platnosti fonémů $/ \mathrm{ts} /, \widehat{\mathrm{t} f} /$ (napřr. Gducie pow $\dot{\bar{e}}(m)$ fwietie każte ćtenie [Jdúce po všem světě, kažte čtenie] BiblVáclNZ 35va). V zápise se navíc objevuje též zdůrazňovací znaménko nad grafem $<\mathrm{v}>$ pro záznam konsonantu /v/ (např. vं $\dot{j}$ elike drevio [všeliké dřevo] BiblVáclNZ 10rb). Nejedná se o diakritické znaménko, protože vokály /ð/, /u:/ jsou psány pravidelně, a to i na začátku slova, grafémem $<\mathrm{u}>$ (např. prziftupili gfu k niemu uczedlnicy jeho a ubudili gfu geho rzkuce [přstúpili jsú k němu učedlníci jeho a ubudili jsú jeho řkúce] BiblVáclNZ 11rb). Jde tedy o další znaménko ve zdůrazňovací funkci, a to proto, aby grafém $<\mathrm{v}>$ byl odlišen od grafému $<\mathrm{y}>$, nebot' jeho spodní dř́ik je vlasový, a tudíž nezřídka málo zřetelný.

$\mathrm{V}$ př́padě rukopisů $\mathrm{s}$ grafémem $<\dot{\mathrm{c}}>\mathrm{v}$ platnosti fonémů $/ \mathrm{ts} / \mathrm{a} / \mathrm{t} \mathrm{f} /$ se tedy nejedná, jak by se mohlo na první pohled zdát, pouze o nadbytečné užívání diakritických znamének, ale jde o souběžné uživání dvou odlišných a významově protichůdných postupů, které se mohou vyskytovat zvláště $v$ přelomových obdobích, kdy na místo staršího způsobu zápisu proniká nový a kdy se nevylučuje koexistence obojího. Podobně jako v konkurenci spřežkového a diakritického pravopisu dochází u většiny středověkých písařù k vytvoření vlastního úzu, který kombinuje prvky obou systémů, uplatňuje se i nadále v různé míře princip zdůrazňovacího znaménka. Důsledkem těchto procesů v českém pravopisu samozřejmě může být i zdánlivě nadměrné a nenáležité užívání diakritiky u některých písařò. Toto přelomové období je navíc poměrně dlouhé, jak dosvědčují rukopisy Nových zákonů z první i druhé poloviny 15 . století.

Zápis konsonantů $/ \widehat{\mathrm{ts}} / \mathrm{a} / \widehat{\mathrm{t} f} /$ stř́idavě grafémy $<\mathrm{c}>,<\dot{\mathrm{c}}>,<\breve{\mathrm{c}}>$ jak v traktátu Orthographia Bohemica, tak v některých biblických rukopisech 15 . století považujeme na základě této úvahy a pramenných dokladů nikoli za prosté chyby, ale za odraz jiného písařského úzu, který znaménka ve formě tečky nebo čárky používal pro zdůraznění grafému, a nikoli pro označení nového, funkčně odlišného grafému, jak je tomu v diakritickém pravopise.

\section{Literatura}

Cejnar J., 1964, Nejstarší české veršované legendy. Soubor rukopisných zlomki̊, Praha.

Daňhelka J., 1985, Směrnice pro vydáváni staršich českých texti̊, „Husitský Tábor“, roč. 8, s. 285-301. Eliáš J.O., 1971, Rukopisy českých biblí v našich knihovnách, disertační práce, Brno.

${ }^{25}$ Praha, Národní knihovna ČR, sign. XVII D 37, 60. léta 15. století, BiblUmučNZ.

${ }^{26}$ Budapest, Magyar Nemzeti Múzeum, sign. Fol. Boh. Slav. 29, 1469, dále BiblVáclNZ. 
Flajšhans V., 1891, Klasobraní po rukopisich. XXIX. Staročeský zlomek evangelia sv. Marka, „Listy filologické“, roč. 18, s. 92-97.

Gaudek T., 2012, K provenienci a datováni Bible boskovické, in: Problematika historických a vzácných knižních fondů Čech, Moravy a Slezska : sborník z 20. odborné konference Olomouc, 20. - 21. zár̆i 2011, ed. R. Krušinský, Olomouc, s. 219-228; online: <http://www.vkol.cz/data/ soubory/import/konf20/21gaudek.pdf>.

Gebauer J., 1878, Ku kvantitě ve staročeských Zlomcích Epických, „Listy filologické“, roč. 5, s. 219-227.

Gebauer J., 1894, Historická mluvnice jazyka českého, Díl I. Hláskosloví, Praha.

Hrbáčová J., Krušinský R., 2016, Chrám věd a múz: 450 let Vědecké knihovny v Olomouci, Olomouc.

Kučera K., 1998, Vývoj účinnosti a složitosti českého pravopisu od konce 13. do konce 20. stol., „Slovo a slovesnost“", roč. 59, s. 178-199.

Kyas V., 1962, Česká předloha staropolského žaltáře, Rozpravy Československé akademie věd. Řada společenských věd, roč. 72, sešit 1 , Praha.

Kyas V., 1971, První český překlad bible, Rozpravy Československé akademie věd. Řada společenských věd, roč. 81 , sešit 1 , Praha.

Michálek M., Němec I., Spunar P., 1984, Jazykovědné a paleografické posouzeni Husova autorství annaberského listu, „Listy filologické“, roč. 107, s. 111-117.

Muzika F., 1958, Krásné písmo ve vývoji latinky, Díl 1., Praha.

Orthographia Bohemica, ed. K. Voleková, Praha 2019.

Pleskalová J., 1998, Tvořeni nejstaršich českých osobnich jmen, Brno.

Pleskalová, J., 2016a, Diakritický pravopis, in: Nový encyklopedický slovník češtiny, eds. P. Karlík, M. Nekula, J. Pleskalová, Praha, s. 331-333; online: <https://www.czechency.org/>.

Pleskalová, J., 2016b, Primitivní pravopis, in: Nový encyklopedický slovník češtiny, eds. P. Karlík, M. Nekula, J. Pleskalová, Praha, s. 1414-1416; online: <https://www.czechency.org/>.

Pleskalová J., P. Kosek, 2016, Spřežkový pravopis, in: Nový encyklopedický slovník češtiny, eds. P. Karlík, M. Nekula, J. Pleskalová, Praha, s. 1746-1750; online: <https://www.czechency.org/>. SS 1968 - Staročeský slovnik. Úvodni stati, soupis pramenů a zkratek, Praha 1968.

Stejskal K., 1986, Rukopis Proroki rožmberských a některé otázky české bible, „Umění“, roč. 34, s. 74-79.

Šlosar D., 2010, Diakritický pravopis, in: Dějiny českého pravopisu (do r. 1902): sborník př́spěvků z mezinárodni konference Dějiny českého pravopisu (do r. 1902) 23.-25. zář́i 2010, Brno, Česká republika, eds. M. Čornejová, L. Rychnovská, J. Zemanová, Brno, s. 200-205.

Vidmanová A., 1982, Ke spisku Orthographia Bohemica, „Listy filologické“, roč. 105, s. 75-89.

Vidmanová A., 1985, K vydáváni latinských textů české provenience ze 14. a 15. století, „Husitský Tábor“, roč. 8, s. 271-283. 


\title{
KATEŘINA VOLEKOVÁ
}

\section{Diacritical signs and signs of non-semantic accentuation in Old Czech manuscripts}

\begin{abstract}
Summary
The article discusses the application of the principles of diacritical orthography in writing Czech words in the Latin treatise Orthographia Bohemica which contains instructions on how digraphs in Czech written texts should be replaced by diacritical signs. While many scholars consider Master Jan Hus to be the author, the treatise was copied by Křriž z Telče (Crux of Telč), a teacher and a priest, by hand into his manuscript convolute at the end of the 1450s. However, Kř́ž failed to write down the exemplary Czech words exactly according to the instructions in the treatise. At first sight, the signs above the letters seem chaotic and inaccurate.

In medieval writings, signs carried out two main functions: first, a sign only accentuated a particular character (sign of non-semantic accentuation) and distinguished it from other, formally similar graphemes (e.g. $<\dot{y}>$ versus $<\mathrm{v}>$ ). Secondly, a sign provided a character with a different meaning (a diacritical sign) and a glyph with a sign represented a phoneme different than a glyph without a sign (e.g. $<\mathrm{z}>$ versus $<\check{\mathrm{z}}>$ ). An orthographic analysis of some Czech biblical manuscripts from both the first and the second half of the $15^{\text {th }}$ century has revealed that scribes used these two systems of accentuation at the same time and combined them. That is why the $c / \mathrm{ts}_{\mathrm{s}} /$ and $\check{c} / \widehat{\mathrm{f}} /$ consonants recorded in the Orthogpraphia Bohemica treatise as either $\langle\mathrm{c}>$ or $<\dot{\mathrm{c}}>$ or $<\check{\mathrm{c}}>$ graphemes cannot be considered a simple scribe's mistake but rather, a reflection of a different scribal usage.
\end{abstract}

Keywords: orthography, Old Czech, Orthographia Bohemica, the Bible, manuscript, signs, diacritical signs, signs of non-semantic accentuation 